Avaiable online at www.babglajol.info

Bangladesh J. Sci. Ind. Res. 43(2), 223-234, 2008

\section{BANGLADESH JOURNAL OF SCIENTIFIC AND INDUSTRIAL RESEARCH}

E-mail: bjsir07gmail.com

\title{
Evaluation of Wheat Germplasm Against Salinity
}

\author{
Farida Begum, ${ }^{a^{*}}$ M. Saifuzzaman ${ }^{\mathrm{b}}$ and W. Sultana ${ }^{\mathrm{a}}$ \\ ${ }^{a}$ Agronomy Division, BARI, Joydebpur, Gazipur. and ${ }^{b}$ WRC, BARI, Gazipur, Bangladesh
}

\begin{abstract}
Fifteen wheat lines/ varieties were tested under artificial saline environment in the year 2006-07 for the study of salt tolerance. Four salinity gradients, 0.38 , 3.76, 8.8 and $12.0 \mathrm{dS}^{-\mathrm{m}}$ were used. Seedling emergence, plant height and crop yield were found to be affected by salinity gradient. The varieties/lines Gaurav, Shatabdi, Sufi, Bijoy. CB-38, CB-60 and CB-78 showed better performance as evaluated on the basis of plant height, yield and yield components. These lines can thus be selected for further investigation in the coastal saline areas. The decrease in growth as attributed to the accumulation of salinity induced increase in $\mathrm{Na}^{+}$and decrease in $\mathrm{K}^{+}$content. This decrease in growth ultimately caused a decrease in yield.
\end{abstract}

Key words : Wheat, Salinity, Crop yield, $\mathrm{Na}^{+}, \mathrm{K}^{+}$content.

\section{Introduction}

In Bangladesh, 52.8 percent of the net cultivated land of the coastal areas is affected by varying degrees of soil salinity (Karim et al 1990). This vast land remains mostly uncultivated except some selected areas where only transplanted aman crop is cultivated. It is presumed that, introduction of salt tolerant crops could be the most acceptable way of intensifying crop production in these areas. Some aspects like seedling development of different crops as also affected by varying level of salinity has been studied previously (Islam et al,1989). However, for successful cultivation, salt tolerant lines/varieties need to be selected. Screening of wheat germplasm against salinity is one of the accepted methods to select lines for saline soil.

\section{Materials and Methods}

The seeds of 15 wheat cultivars/lines (Shatabdi, Gaurav, Sufi, Saurav, Bijoy, CB7, CB-19,CB-35, CB-37, CB-38, CB-44, CB-55, CB-60, CB-72 and CB-78) have been for the study. To observed yield variation, plants were grown in seed beds ( $2 \mathrm{~m} \times 1$ m) using standard recommended fertilizer

\footnotetext{
* Corresponding author
} 
dose (110-35-25-22 kg/h of NPKS). The experiment was carried out in four diefferent seed beds. These four seed beds were prepared with different salinity levels. The salinity levels were raised to $0.38 \mathrm{dS}^{-\mathrm{m}}, 3.76$ $\mathrm{dS}^{-\mathrm{m}} 8.80 \mathrm{dS}^{-\mathrm{m}}$ and $12.0 \mathrm{dS}^{-\mathrm{m}}$ by adding $\mathrm{NaCl}$ solution externally. Each bed was divided into fifteen rows and each raw represents a different variety. Line to line distance was about $15 \mathrm{~cm}$. Eighty seeds were sown continuously. Yield and yield component data were recorded after harvesting. The values in the tables represents the mean of ten replicates. Sodium and potassium ions were collected by boiling the dry tissues with distilled water and measured the amount by Flame photometer (Kormoker and Van Steveninck.
1978). The amount of ions presented in table IX is the mean value of four replicates.

\section{Results and Discussion}

A variation on the emergence of wheat seedlings among the varieties/lines under salinity has been investigated. The number of plants per meter of the row that emerged under salinity is presented in the Table I. The relative emergence as per control is shown in Fig. 1. It is ovserved from Table I and Fig.1 that at lower salinity of $3.76 \mathrm{dS}^{-\mathrm{m}}$, the lines Gaurav, Sufi and CB-19 showed a stimulatory effect, whereas Shatabdi and Saurav showed a decrease in emergence number as per control and this decrease was within $20 \%$. The most affected lines under higher salinity regarding seedling emergence were

Table I. Plant population/m as influenced by salinity.

\begin{tabular}{l|c|c|c|c}
\hline \multirow{2}{*}{ Varieties/lines } & \multicolumn{4}{|c}{ No. of plant/m } \\
\cline { 2 - 5 } & \multicolumn{4}{|c}{ Salinity level } \\
\cline { 2 - 5 } & $0.38 \mathrm{dS} / \mathrm{m}$ & $3.76 \mathrm{dS} / \mathrm{m}$ & $8.80 \mathrm{dS} / \mathrm{m}$ & $12.0 \mathrm{dS} / \mathrm{m}$ \\
\hline Shatabdi & 48 & 41 & 21 & 7 \\
CB-55 & 57 & 40 & 21 & 3 \\
CB-37 & 75 & 22 & 10 & 5 \\
CB-7 & 50 & 31 & 4 & 0 \\
CB-35 & 57 & 33 & 9 & 0 \\
Gaurav & 34 & 44 & 26 & 15 \\
CB-78 & 63 & 26 & 31 & 2 \\
CB-38 & 36 & 17 & 24 & 9 \\
Sufi & 36 & 40 & 20 & 5 \\
CB-44 & 45 & 34 & 5 & 1 \\
CB-19 & 45 & 55 & 7 & 5 \\
CB-60 & 46 & 24 & 24 & 3 \\
Saurav & 55 & 50 & 30 & 13 \\
Bijoy & 59 & 27 & 11 & 5 \\
CB-72 & 51 & 20 & 17 & 5 \\
Mean & 50 & 34 & & 5 \\
\hline
\end{tabular}




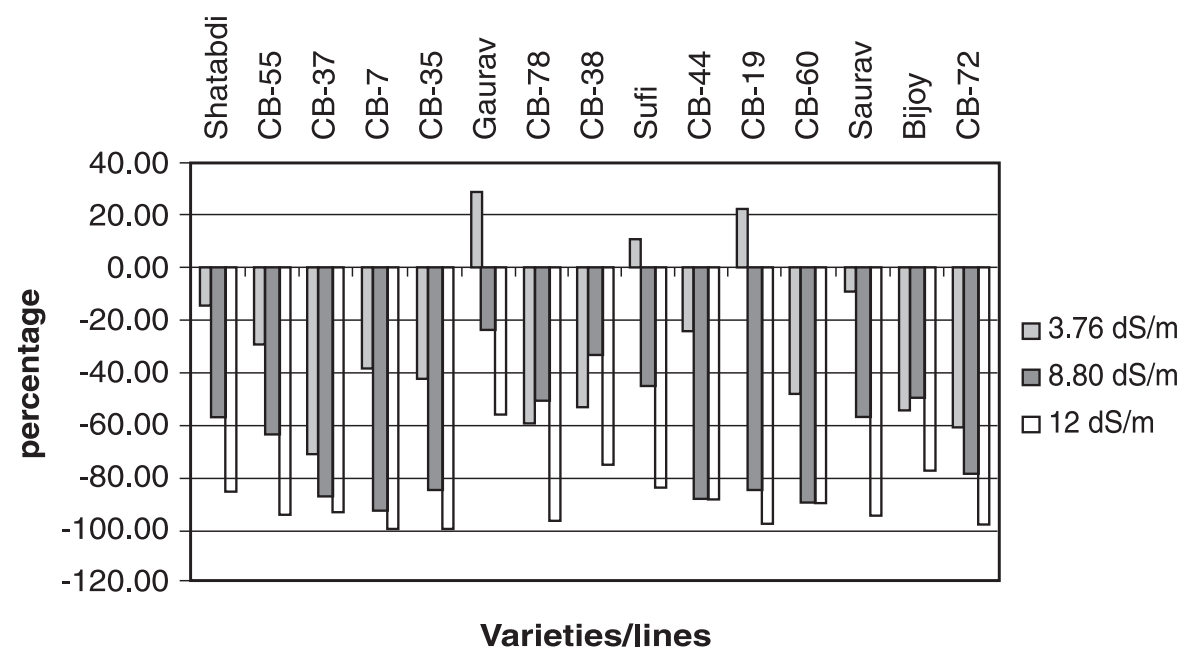

Fig. 1. Relative plant population as per control

CB-7, CB-35 and CB-37. At 12 dS ${ }^{-\mathrm{m}}$, CB-7 and $\mathrm{CB}-35$ failed to germinate and other varieties/lines affected seriously.
Plant hieght as influenced by salinity and relative plant height as compared to control were presented in Table II and Fig 2 respectively. Most of lines/varieties were not affected under salinity up to $8.80 \mathrm{dS}^{-\mathrm{m}}$.

Table II. Plant height as influenced by salinity.

\begin{tabular}{|c|c|c|c|c|}
\hline \multirow{3}{*}{ Varieties/lines } & \multicolumn{4}{|c|}{ Plant height } \\
\hline & \multicolumn{4}{|c|}{ Salinity level } \\
\hline & $0.38 \mathrm{dS} / \mathrm{m}$ & $3.76 \mathrm{dS} / \mathrm{m}$ & $8.80 \mathrm{dS} / \mathrm{m}$ & $12.0 \mathrm{dS} / \mathrm{m}$ \\
\hline Shatabdi & 68.6 & 67.0 & 66.2 & 54.4 \\
\hline CB-55 & 69.6 & 67.0 & 64.2 & 50.3 \\
\hline CB-37 & 73.2 & 64.2 & 61.6 & 47.6 \\
\hline CB-7 & 71.0 & 69.4 & 51.5 & 0 \\
\hline CB-35 & 66.4 & 68.4 & 59.6 & 0 \\
\hline Gaurav & 83.4 & 78.0 & 65.6 & 67.0 \\
\hline CB-78 & 75.2 & 66.0 & 61.0 & 47.0 \\
\hline CB-38 & 73.6 & 63.6 & 68.2 & 55.8 \\
\hline Sufi & 76.2 & 67.6 & 60.1 & 56.4 \\
\hline CB-44 & 65.8 & 47.6 & 41.0 & 47.8 \\
\hline CB-19 & 76.4 & 71.6 & 27.0 & 27.0 \\
\hline CB-60 & 67.6 & 67.0 & 53.4 & 52.2 \\
\hline Saurav & 68.8 & 71.0 & 72.6 & 39.7 \\
\hline Bijoy & 72.6 & 74.4 & 71.2 & 59.4 \\
\hline CB-72 & 80.0 & 65.6 & 67.6 & 46.0 \\
\hline Mean & 73 & 67 & 59 & 44 \\
\hline
\end{tabular}




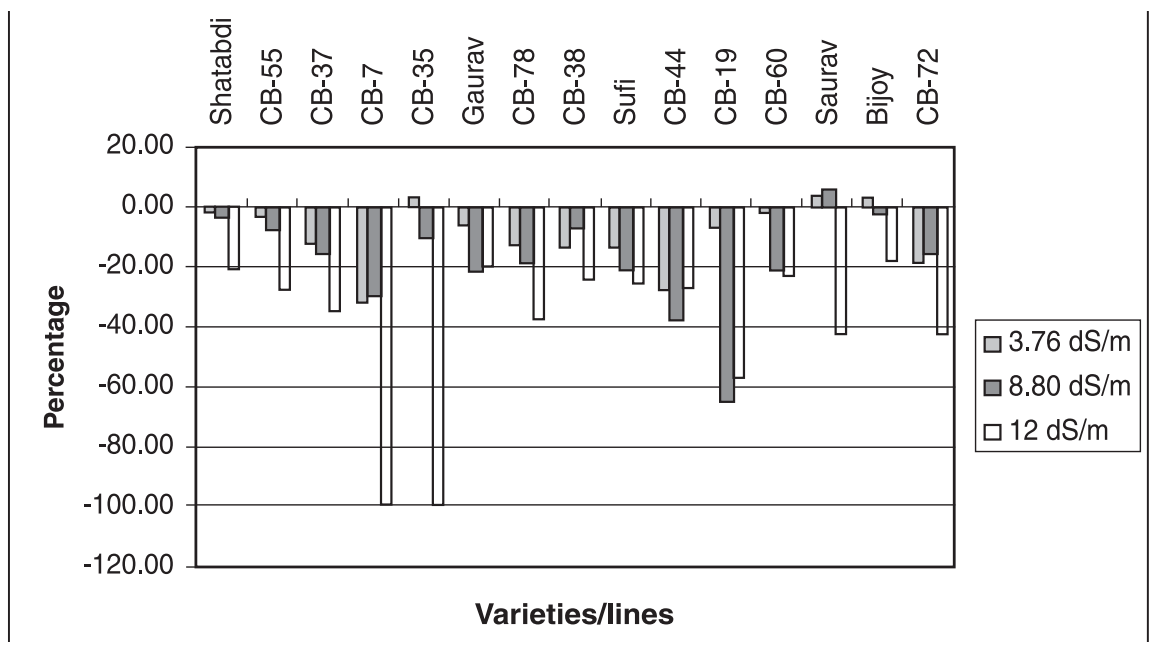

Fig. 2. Relative plant height as per control

From Fig. 2 it is obvious that plant height was not affected under salinity up to $8.80 \mathrm{dS}^{-\mathrm{m}}$. The highest decrease in plant height (55\%) as per control was observed in CB-19 which is followed by CB72 (43\%) and Saurav (42\%) at $12.0 \mathrm{dS}^{-\mathrm{m}}$.
Yield and yield components are also affected by salinity (Tables III to VII). From the consideration fo spike length (Table III), Sufi, Gaurav and CB-38 showed better performance in comparison with control under higher salinity like $12.0 \mathrm{dS}^{-\mathrm{m}}$ (Fig-3).

Table III. Spike length of wheat as influenced by salinity.

\begin{tabular}{l|c|c|c|c}
\hline \multirow{2}{*}{ Varieties/lines } & \multicolumn{4}{|c}{ Spike length (cm) } \\
\cline { 2 - 5 } & \multicolumn{4}{|c}{ Salinity level } \\
\cline { 2 - 5 } & $0.38 \mathrm{dS} / \mathrm{m}$ & $3.76 \mathrm{dS} / \mathrm{m}$ & $8.80 \mathrm{dS} / \mathrm{m}$ & $12.0 \mathrm{dS} / \mathrm{m}$ \\
\hline Shatabdi & 9.90 & 9.90 & 9.60 & 7.96 \\
CB-55 & 10.00 & 11.00 & 10.90 & 9.00 \\
CB-37 & 10.20 & 10.8 & 10.50 & 8.60 \\
CB-7 & 10.80 & 10.56 & 7.63 & 0 \\
CB-35 & 7.40 & 8.76 & 9.40 & 0 \\
Gaurav & 9.60 & 8.60 & 9.80 & 8.80 \\
CB-78 & 9.60 & 9.30 & 9.50 & 8.00 \\
CB-38 & 10.00 & 9.44 & 10.4 & 9.10 \\
Sufi & 10.00 & 10.40 & 10.00 & 9.50 \\
CB-44 & 8.80 & 8.30 & 8.00 & 5.00 \\
CB-19 & 9.00 & 7.20 & 6.50 & 7.80 \\
CB-60 & 9.80 & 9.70 & 8.50 & 7.30 \\
Saurav & 10.10 & 10.20 & 10.00 & 9.90 \\
Bijoy & 11.00 & 11.40 & 11.60 & 7.00 \\
CB-72 & 10.70 & 10.10 & 10.30 & 7 \\
Mean & 10 & 10 & 9 & \\
\hline
\end{tabular}




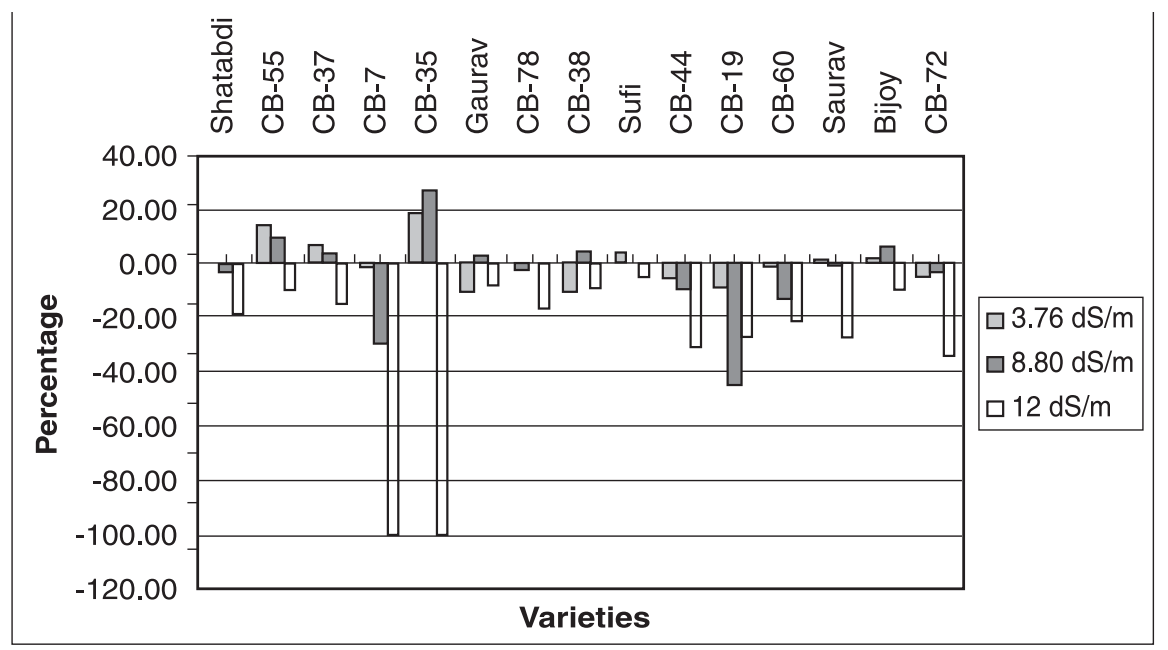

Fig. 3. Relative length of spike as per control

Number of spikelet/spike as affected by shows a stimulatory effect up to $8.8 \mathrm{dS}^{-\mathrm{m}}$ ( $6 \%$ salinity is presented in Table IV. CB-60 increase as per control) Number of shows better performance under salinity seed/spike is reduced under salinity ranging ranging from 3.76 to $12.0 \mathrm{dS}^{-\mathrm{m}}$. Variety Bijoy from 3.76 to $12 \mathrm{dS}^{-\mathrm{m}}$ (Table V). Less than

Table IV. No. of Spikelet/spike of wheat as influenced by salinity.

\begin{tabular}{|c|c|c|c|c|}
\hline \multirow{3}{*}{ Varieties/lines } & \multicolumn{4}{|c|}{ Spikelet/spike } \\
\hline & \multicolumn{4}{|c|}{ Salinity level } \\
\hline & $0.38 \mathrm{dS} / \mathrm{m}$ & $3.76 \mathrm{dS} / \mathrm{m}$ & $8.80 \mathrm{dS} / \mathrm{m}$ & $12.0 \mathrm{dS} / \mathrm{m}$ \\
\hline Shatabdi & 17 & 17 & 15 & 13 \\
\hline CB-55 & 19 & 21 & 18 & 16 \\
\hline CB-37 & 18 & 17 & 16 & 13 \\
\hline CB-7 & 17 & 18 & 14 & 0 \\
\hline CB-35 & 16 & 16 & 15 & 0 \\
\hline Gaurav & 18 & 18 & 17 & 17 \\
\hline CB-78 & 18 & 18 & 16 & 14 \\
\hline CB-38 & 18 & 18 & 17 & 15 \\
\hline Sufi & 19 & 18 & 18 & 18 \\
\hline CB-44 & 16 & 15 & 12 & 15 \\
\hline CB-19 & 16 & 16 & 9 & 9 \\
\hline CB-60 & 17 & 16 & 16 & 16 \\
\hline Saurav & 18 & 17 & 17 & 11 \\
\hline Bijoy & 17 & 18 & 18 & 15 \\
\hline CB-72 & 18 & 17 & 17 & 13 \\
\hline Mean & 17 & 17 & 16 & 12 \\
\hline
\end{tabular}




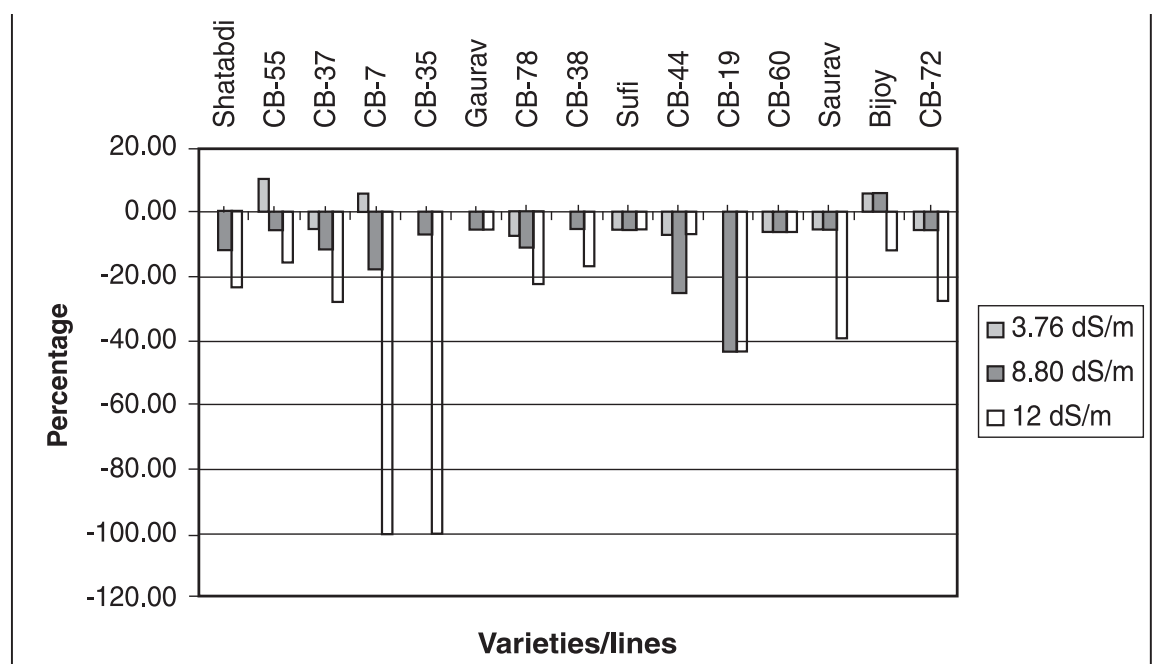

Fig. 4. Relative spikelet number per spike as per control

$10 \%$ reduction in the number of seed/spike is control is observed in CB-72, when no. of ovserved in Gaurav, Sufi, Saurav, CB-60, seeds/spike is considered (Table V, fig. 5). CB-72 and CB-78 at lower salinity (3.76 $\mathrm{dS}^{-\mathrm{m}}$ ). At $12 \mathrm{dS}^{-\mathrm{m}}$, the maximum decrease as per Thousand grain weights which is an important yield contributing character are presented

Table V. No. of seeds/spike as influenced by salinity.

\begin{tabular}{l|c|c|c|c}
\hline \multirow{2}{*}{ Varieties/lines } & \multicolumn{4}{|c}{ Seed/spike } \\
\cline { 2 - 5 } & \multicolumn{4}{|c}{ Salinity level } \\
\cline { 2 - 5 } & $0.38 \mathrm{dS} / \mathrm{m}$ & $3.76 \mathrm{dS} / \mathrm{m}$ & $8.80 \mathrm{dS} / \mathrm{m}$ & $12.0 \mathrm{dS} / \mathrm{m}$ \\
\hline Shatabdi & 40 & 36 & 32 & 21 \\
CB-55 & 37 & 27 & 30 & 29 \\
CB-37 & 38 & 39 & 33 & 24 \\
CB-7 & 43 & 34 & 23 & 0 \\
CB-35 & 38 & 39 & 31 & 0 \\
Gaurav & 37 & 35 & 30 & 21 \\
CB-78 & 39 & 33 & 31 & 32 \\
CB-38 & 37 & 32 & 31 & 27 \\
Sufi & 36 & 34 & 24 & 26 \\
CB-44 & 35 & 28 & 29 & 22 \\
CB-19 & 32 & 33 & 32 & 22 \\
CB-60 & 35 & 40 & 30 & 20 \\
Saurav & 40 & 30 & 29 & 12 \\
Bijoy & 35 & 45 & 29 & 22 \\
CB-72 & 45 & 34 & & 29 \\
Mean & 38 & \multicolumn{4}{|c}{} & \\
\hline
\end{tabular}




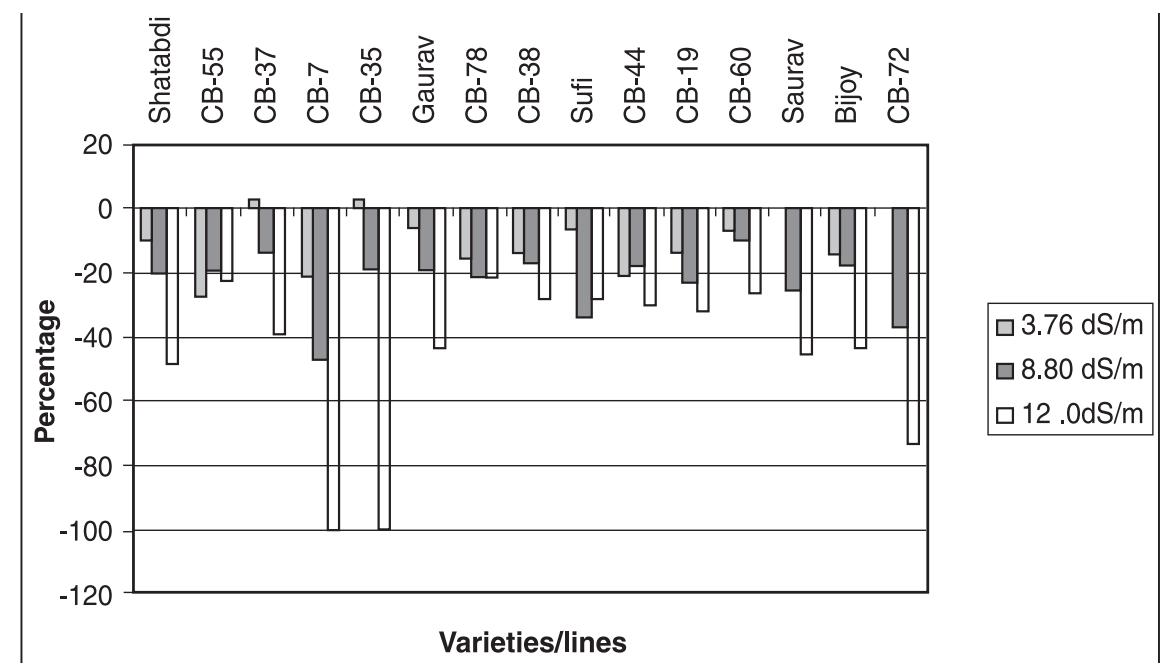

Fig. 5. Relative no. of seeds/spike as per control as influenced by salinity

in Table VI. The mean thousand grain weights is $31 \mathrm{~g}$ and it decrease with increase in s alinity. Varieties/lines Gaurav, Sufi,
Bijoy, CB-19, CB-44, CB-60 shows stimulatory affect at lower salinity $\left(3.76 \mathrm{dS}^{-\mathrm{m}}\right)$ (fig.6). At higher salinity (12.0 dS ${ }^{-\mathrm{m}}$ ), Bijoy,

Table VI. Thousand grain wt. as influenced by salinity

\begin{tabular}{l|c|c|c|c}
\hline \multirow{2}{*}{ Varieties/lines } & \multicolumn{4}{|c}{ 1000-grain wt. (g) } \\
\cline { 2 - 5 } & \multicolumn{3}{|c}{ Salinity level } \\
\cline { 2 - 5 } & $0.38 \mathrm{dS} / \mathrm{m}$ & $3.76 \mathrm{dS} / \mathrm{m}$ & $8.80 \mathrm{dS} / \mathrm{m}$ & $12.0 \mathrm{dS} / \mathrm{m}$ \\
\hline Shatabdi & 33.75 & 33.00 & 33.20 & 28.08 \\
CB-55 & 33.50 & 31.25 & 31.50 & 25.93 \\
CB-37 & 33.60 & 29.05 & 32.30 & 32.30 \\
CB-7 & 38.15 & 34.65 & 24.22 & 0 \\
CB-35 & 32.25 & 20.45 & 20.10 & 0 \\
Gaurav & 27.00 & 27.50 & 27.25 & 21.10 \\
CB-78 & 27.30 & 25.80 & 25.90 & 24.38 \\
CB-38 & 29.50 & 27.20 & 27.80 & 27.55 \\
Sufi & 28.35 & 29.30 & 25.30 & 25.30 \\
CB-44 & 25.00 & 26.25 & 22.50 & 22.20 \\
CB-19 & 32.40 & 33.15 & 25.00 & 23.64 \\
CB-60 & 31.40 & 33.10 & 30.50 & 30.10 \\
Saurav & 35.30 & 28.30 & 34.65 & 30.27 \\
Bijoy & 32.25 & 27.35 & 33.90 & 30.65 \\
CB-72 & 28.15 & 27.30 & 32.90 & 25.83 \\
Mean & 31 & 29 & 28 & 23 \\
\hline
\end{tabular}




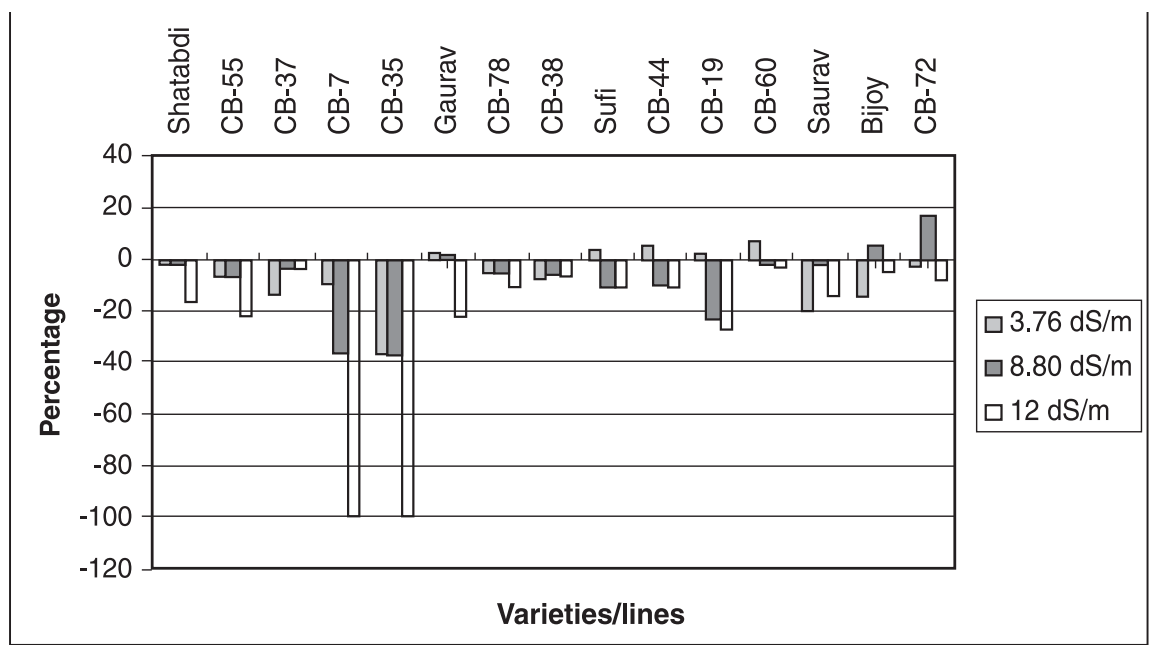

Fig. 6. Relative weight of thousand grains as per control

Sufi, CB-37, CB-38, CB-44, CB-60, CB-72 to $8.8 \mathrm{dS}^{-\mathrm{m}}$ salinity. CB-60 and CB-78 and CB-78 shows better tolerance. Thousand showed better performance at $12.0 \mathrm{dS}^{-\mathrm{m}}$ also. grain weight did not varied in Gaurav, Bijoy, CB-19, CB-37, CB-60, CB-72 and CB-78 up Yield/plant data is shown in Table VII and fig. 7. The mean yield/plant under salinity

Table VII. Yield/plant as influenced by salinity.

\begin{tabular}{l|c|c|c|c}
\hline \multirow{2}{*}{ Varieties/lines } & \multicolumn{4}{|c}{ Yield/plant } \\
\cline { 2 - 5 } & \multicolumn{4}{|c}{ Salinity level } \\
\cline { 2 - 5 } & $0.38 \mathrm{dS} / \mathrm{m}$ & $3.76 \mathrm{dS} / \mathrm{m}$ & $8.80 \mathrm{dS} / \mathrm{m}$ & $12.0 \mathrm{dS} / \mathrm{m}$ \\
\hline Shatabdi & 1.12 & 1.09 & 0.51 & 0.5 \\
CB-55 & 1.32 & 1.13 & 0.99 & 0.48 \\
CB-37 & 1.30 & 1.11 & 1.29 & 0.79 \\
CB-7 & 0.78 & 0.9 & 0.55 & 0 \\
CB-35 & 1.12 & 0.7 & 0.42 & 0 \\
Gaurav & 0.80 & 0.82 & 0.82 & 0.43 \\
CB-78 & 0.97 & 0.88 & 0.91 & 0.78 \\
CB-38 & 1.02 & 0.9 & 0.91 & 0.77 \\
Sufi & 1.15 & 1.04 & 0.88 & 0.81 \\
CB-44 & 0.83 & 0.65 & 0.63 & 0.31 \\
CB-19 & 0.62 & 0.73 & 0.64 & 0.79 \\
CB-60 & 1.01 & 0.93 & 0.98 & 0.55 \\
Saurav & 1.34 & 0.94 & 0.71 & 0.63 \\
Bijoy & 0.99 & 0.91 & 0.94 & 0.49 \\
CB-72 & 1.54 & 1.39 & 1.4 & 0.52 \\
Mean & 0.99 & 0.94 & 0.84 & \\
\hline
\end{tabular}




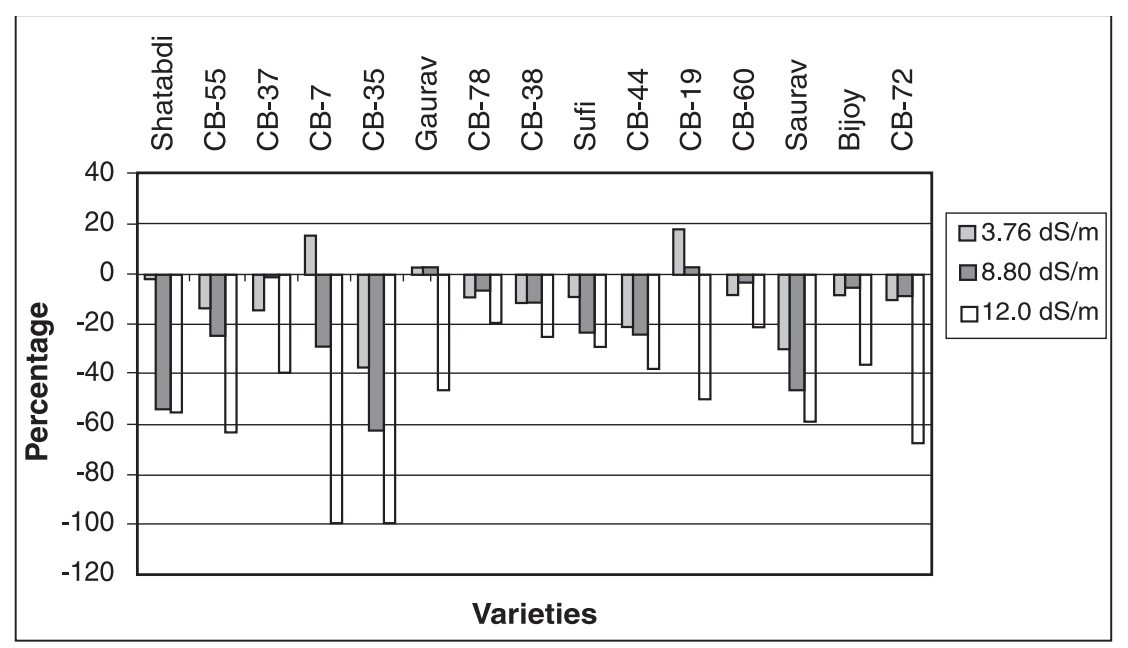

Fig. 7. Relative yield/plant as per control as influenced by salinity

Table VIII. Yield/m as influenced by salinity

\begin{tabular}{l|c|c|c|c}
\hline \multirow{2}{*}{ Varieties/lines } & \multicolumn{4}{|c}{ Yield/m (g) } \\
\cline { 2 - 5 } & \multicolumn{3}{|c}{ Salinity level } \\
\cline { 2 - 5 } & $0.38 \mathrm{dS} / \mathrm{m}$ & $3.76 \mathrm{dS} / \mathrm{m}$ & $8.80 \mathrm{dS} / \mathrm{m}$ & $12.0 \mathrm{dS} / \mathrm{m}$ \\
\hline Shatabdi & 24.65 & 24.01 & 22.84 & 4.1 \\
CB-55 & 27.43 & 25.27 & 20.74 & 3.95 \\
CB-37 & 30.21 & 24.50 & 12.89 & 3.94 \\
CB-7 & 39.37 & 28.02 & 02.18 & 0 \\
CB-35 & 23.96 & 22.95 & 10.10 & 0 \\
Gaurav & 26 & 26.18 & 21.30 & 6.48 \\
CB-78 & 22.47 & 22.87 & 28.34 & 1.56 \\
CB-38 & 27.75 & 25.30 & 21.82 & 9.16 \\
Sufi & 41.55 & 35.05 & 30 & 6.23 \\
CB-44 & 22.73 & 22.08 & 04.15 & 4.01 \\
CB-19 & 27.88 & 20.40 & 01.05 & 0.7 \\
CB-60 & 29.21 & 22.42 & 04.88 & 3.95 \\
Saurav & 30.08 & 46.79 & 32.22 & 2.13 \\
Bijoy & 30.73 & 24.59 & 28.06 & 8.16 \\
CB-72 & 26.65 & 15.46 & 15.42 & 0.49 \\
Mean & 28.71 & 25.73 & 17.07 & 3.66 \\
\hline
\end{tabular}




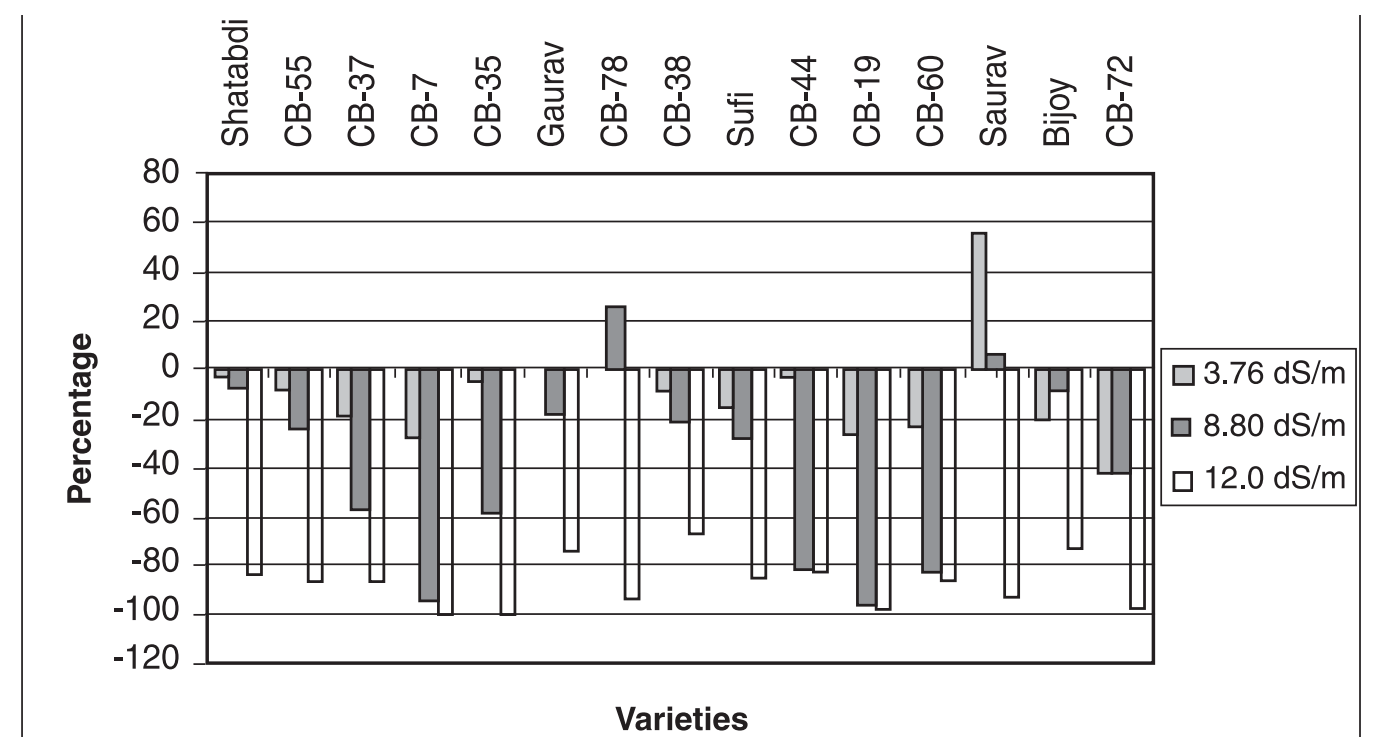

Fig. 8. Relative yield/m as per control as influenced by salinity

condition is $0.99 \mathrm{~g}$ which decrease to $0.52 \mathrm{~g}$ at $12.0 \mathrm{dS}^{-\mathrm{m}}$.

Shatabdi, Bijoy, Saurav and CB-78 performed better at $8.80 \mathrm{dS}^{-\mathrm{m}}$ considering yield/m (Table VIII and fig. 8).

A decrease in germination and plant height under salinity were also observed in barley (Sultana et al. 1999) and also in maize (Begum et al 2000) in the case of wheat, accumulation of $\mathrm{Na}^{+}$ions increased and $\mathrm{K}^{+}$ content decreased (Table IX). It is well known that $\mathrm{Na}^{+}$is toxic to that plant, while $\mathrm{K}^{+}$acts as activator of many metabolic processes like photosynthesis, protein synthesis and respiration (Clarkson, 1974). Thus decrease in growth might be due to accumulation of excess amounts of $\mathrm{Na}^{+}$with a concomitant decrease in $\mathrm{K}^{+}$. Wheat plants need 2 to 3\% excess energy to survive under stress condition (Lennard and Galloway, 1990). This might have caused a decrease in growth and ultimately a decrease in yield.

From this result, it is obvious that yield/plant of wheat decreased under salinity by different amounts depending on the variety of wheat as reflected in the plant height, yield and yield components. A decrease in yield was also observed in green gram (Patil et al 1992), in Finger millet (Onkware, 1993) and also in rice (Dubey, and Rani,1989) at higher salinity. Hence it is concluded that salinity induced reduction in growth is due to accumulation of excess amount of $\mathrm{Na}^{+}$and $\mathrm{Cl}^{-}$with a concomitant decrease in $\mathrm{K}^{+}$. This 
Table IX. Effect of salinity of accumulation and distribution $\mathrm{Na}^{+}$and $\mathrm{K}^{+}$

\begin{tabular}{l|c|c|c|c}
\hline \multirow{2}{*}{$\begin{array}{l}\text { Salinity level } \\
\left(\mathrm{ds}^{-\mathrm{m}}\right)\end{array}$} & \multicolumn{4}{|c}{ Ion accumulation (mg/g dry tissue) } \\
\cline { 2 - 5 } & \multicolumn{2}{|c|}{$\mathrm{Na}^{+}$} & Root & Soot \\
\cline { 2 - 5 } & Root & Soot & 22.93 & 19.5 \\
\hline 0 & 5.29 & 4.19 & 19.89 & 18.63 \\
8 & 34.27 & 10.58 & 7.8 & 17.55 \\
12 & 49.3 & 23.92 & \\
\hline
\end{tabular}

reduction in growth ultimately results in the reduction of yield.

\section{Conclusion}

Of the fifteen varieties/lines which were tested experimentally against salinity in respected of their performance evaluated on the basis of seedling emergence, plant height, yield and yield component, Gaurav, Shatabdi, Sufi, Bijoy. CB-38, CB-60 and CB-78 showed better results. These varieties/lines can be chosen for cultivation in the saline belt of Bangladesh. The mechanism controlling the decrease in yield has been identified as due to a salinity induced increas in $\mathrm{Na}^{+}$and decrease $\mathrm{K}^{+}$content.

\section{References}

Begum, F., Sarker B.C. Houque S. (2000). Effect of salinity on growth and accumulation of $\mathrm{Na}^{+}, \mathrm{K}^{+}$, and $\mathrm{Cl}^{-}$in maize (Zea mays) Dhaka Univ. J. Biol. Sci. 9(2):a93-198.
Clarkson, D. (1974). In Ion Transport Cell Structure in plants. Published by Mc. GrowHills Book Company (UK) Ltd. Maidenhead Berkshire, England.

Dubey, R.S. Rani M. (1989). Influence of $\mathrm{NaCl}$ salinity on growth and metabolic status of protein and amino acids in rich seedlings. Journal of Agronomy and Crop Science. 162(2): 97-106.

Lennard, Ed Barrett, Darison N. and Galloway R.P. (1990). Plant growth and survival in saline water-logged soils. W. A Journal of Agriculture. 31: 56-57.

Islam, A.K.M.N., Fauzia K. Balasubramanium S. (1989). Seedling growth of wheat and rice cultivars in relation to salinity. Bionature 9(1): 25-28.

Karim, Z. Hossain G.G., Ahmed M. (1990). Salinity problem and crop intensification in coastal rigion of Bangladesh. BARC Soil Publication. No. 33. 
Kormoker, J.L. Van stevenink R.E.M. (1978). Stimulation of volume flow and ion flux by abscisic acid in excised root systems of Phaseolus vulgare cv. Redland Pioneer. Planta. 141: 37-43.

Onkware, Augustino Osoro, (1993). The germination growth and grain production of salt stress 1983 finger millet, Elunsine caracana. Indian J. Plant Physiol 36(2): 77-81.

Patil, S.L., Hunshal C.S.,, Viswanath D.P., Chimmad V.P., Sali S.B. Hosmani R.M. (1992). Effect of saline water irrigation on soil properties. Indian $J$. Maharashtra Agric.Univ. 17(2): 229-231.
Sultana, W., Begum F., Saifuzzaman M., Nessa A. Salahuddin A.B.B.M. (1999). Performance of three barley cultivars at early growth stages. Bang. J. Sci. and Tech. 1(1): 29-34.

Received : September, 24, 2007;

Accepted : January, 03, 2008. 